\title{
Association between the ACE-I/D polymorphism and nicotine dependence amongst patients with lung cancer
}

\author{
SERGEJ NADALIN ${ }^{1}$, VELJKO FLEGO ${ }^{2}$, SANJA DEVIĆ PAVLIĆ ${ }^{1}$, DARIAN VOLARIĆ ${ }^{1}$, \\ ANĐELKA RADOJČIĆ BADOVINAC ${ }^{1,3}$, MILJENKO KAPOVIĆ ${ }^{1}$ and SMILJANA RISTIĆ ${ }^{1}$ \\ ${ }^{1}$ Department of Medical Biology and Genetics, Faculty of Medicine, University of Rijeka; ${ }^{2}$ Department of Pulmonology, \\ Clinical Hospital Center Rijeka; ${ }^{3}$ Department of Biotechnology, University of Rijeka, 51000 Rijeka, Croatia
}

Received July 7, 2020; Accepted September 14, 2020

DOI: $10.3892 /$ br.2020.1365

\begin{abstract}
The biologically active peptide angiotensin II is cleaved from angiotensinogen by the renin and the angiotensin-converting enzyme (ACE), an enzymatic cascade known as the renin-angiotensin system (RAS). RAS may be important in the etiology of nicotine dependence by influencing dopaminergic signaling. In the present study, the association between an insertion/deletion (I/D) polymorphism of ACE and nicotine dependence amongst patients with lung cancer was assessed. To date, several studies have shown the relevance of this polymorphic variant in both nicotine dependence and lung cancer. However, the present study is the first to address the potential role of the ACE-I/D polymorphism in nicotine dependence among patients with lung cancer. Genotyping was performed in 305 patients with lung cancer (males/females, 214/91). Significantly more male smokers had the ACE-I allele compared with male non-smokers (44.9 vs. $20.0 \%$; $\mathrm{P}<0.05$ ). The risk of smoking was $\sim 5$-fold higher for males with the ACE-I allele (ACE-II homozygous and ACE-ID heterozygous) vs. ACE-DD homozygous (odds ratio, 5.47; 95\% confidence interval, 1.4-21.9; $\mathrm{P}=0.016$ ). The pack-year smoking history in a subgroup of females with squamous cell carcinoma carrying the ACE-I allele was significantly lower compared with ACE-DD (37.1 14.1 vs. 57.0 $\pm 29.1 ; \mathrm{F}=4.5 ; \mathrm{P}=0.046$ ). The $\mathrm{ACE}-\mathrm{I} / \mathrm{D}$ polymorphism accounted for $17.6 \%$ of the smoking severity in this patient group $\left(\beta,-0.42\right.$; multiple $\mathrm{R}^{2}$ change, $\left.0.176 ; \mathrm{P}=0.046\right)$. These results suggest that the ACE-I/D polymorphism contributes to the risk of nicotine dependence and smoking severity in lung cancer patients in a sex-specific manner.
\end{abstract}

Correspondence to: Dr Sergej Nadalin, Department of Medical Biology and Genetics, Faculty of Medicine, University of Rijeka, Braće Branchetta 20, 51000 Rijeka, Croatia

E-mail: sergej.nadalin@medri.uniri.hr

Key words: angiotensin-converting enzyme gene, insertion/deletion polymorphism, lung cancer, nicotine dependence

\section{Introduction}

Lung cancer is a multifactorial disease with a complex interplay of genetic and environmental factors contributing to its progression. Environmental exposure, primarily to smoking, is the most well-established environmental risk factor for this disease $(1,2)$. A previous meta-analysis, which included a large number of participants of European ancestry (n, 29,179), revealed that current male smokers with an average daily dose of $>30$ cigarettes had an odds ratios (ORs) of 103.5 for squamous cell carcinoma, 111.3 for small cell lung cancer and 21.9 for adenocarcinoma. In women, the corresponding ORs were 62.7, 108.6 and 16.8, respectively (3).

Although cigarette smoke contains $>4,000$ ingredients, the pharmacological effects of tobacco addiction are known to be primarily mediated by nicotine (4-7). Binding of nicotine to nicotinic cholinergic receptors results in stimulation of brain mesolimbic dopaminergic neurons, and these are hypothesized to underlie the addiction to tobacco/nicotine (8-12). Nicotine itself is not carcinogenic; however, nicotine dependence may be indirectly associated with an elevated risk of lung cancer through increasing smoking and consequently increasing tobacco carcinogen intake $(1,13)$. Genome wide association studies of lung cancer have identified a locus on chromosome 15q25.1 that encodes three (CHRNA3, CHRNA5 and CHRNB4) of the eleven nicotinic acetylcholine receptor subunits in the brain mesolimbic system, and this is the most significant genome-wide location for lung cancer and nicotine dependence (14-16).

The activity of the renin-angiotensin system (RAS) is dependent on angiotensin II, which is a biologically active peptide generated from angiotensinogen via cleavage by renin and angiotensin-converting enzyme (ACE) (17-19). Although the classical function of the RAS is regulation of blood pressure and cardiovascular homeostasis (20), several studies have suggested that the RAS may also be important in the etiology of nicotine dependence by influencing dopaminergic signaling (21-23). Angiotensin II interacts with dopamine in mesocorticolimbic areas as a neurotransmitter, and ACE regulates turnover of dopamine in the rat striatum $(21,22)$. Furthermore, dopamine release in the rat striatum exhibits a decreased response to captopril and enalaprilat, both antihypertensive drugs that inhibit the activity of ACE (23). 
A functional insertion/deletion (I/D) polymorphism (rs1799752) in intron 16 of the ACE gene (17q23), which is characterized by the presence or absence of a 287 bp Alu repetitive sequence, accounts for $\sim 50 \%$ of the ACE levels (24) and is the most widely-studied RAS-related polymorphic variant, and the only RAS-related polymorphism investigated in the etiology of nicotine dependence (25-29). To date, several studies have addressed the potential relevance of the ACE-I/D polymorphism in the etiology of nicotine dependence, but the results have been inconsistent (25-29). For example, there is a significantly greater risk of being a smoker observed amongst ACE-DD homozygous individuals suffering from depression in the German population (27) and amongst heterozygous (ID) females with schizophrenia in the Croatian population (29). Conversely, studies consisting of healthy subjects from the Czech Republic and German populations $(26,27)$ and multiple sclerosis patients from the Croatian population (28) found no evidence of an association between the ACE-I/D polymorphism and the risk of smoking. The ACE-I/D polymorphic variant may also serve a role in smoking severity; the ACE-DD homozygous genotype was shown to contribute to an increase in the number of cigarettes smoked per day amongst patients suffering from depression, as well as an increase in the pack-years of smoking history amongst healthy individuals in the German population (27).

Numerous studies have investigated the influence of the ACE-I/D polymorphism in the etiology of lung cancer in European and Asian populations, but the conclusions of the studies are often contradictory (30-37). A meta-analysis showed no significant associations between the ACE-I/D polymorphic variant and the risk of lung cancer $(38,39)$. In contrast, in our previous study in lung cancer patients from a Croatian population, the ACE-I/D polymorphism was shown to be associated with a higher risk of developing squamous cell carcinoma (35), which is strongly associated with smoking $(3,40)$. In these patients, there was a significantly higher frequency of the ACE-DD genotype and ACE-D allele compared with the control group. Based on this finding and the hypothesis that the RAS may be involved in brain dopaminergic signaling (20-22), in the present study, whether the ACE-I/D polymorphism influenced smoking behavior amongst patients with lung cancer was investigated.

\section{Patients and methods}

Study participants. The study group recruited in the present consisted of 305 lung cancer patients who were treated at the Department of Pulmonology in the Clinical Hospital Center in Rijeka, Croatia. The patients' demographic and clinical characteristics are shown in Table I. Histology was graded according to the World Health Organization classification method (41) and the classification of tumor stages according to the Tumor-Node-Metastasis staging system (42). Patients were divided into smokers and non-smokers using data from questionnaires, with smokers defined as individuals who smoked $>1$ cigarette per day for $>1$ year and non-smokers defined as those who had smoked $<100$ cigarettes during their lifetime $(43,44)$. The numbers of quitters, occasional smokers, ex-smokers as well as those who had been smoking for $<1$ year were too small for statistical analysis and were thus excluded from the present study. To assess the severity of nicotine dependence, patients were also asked for their pack-year smoking history, which was calculated as follows: Number of cigarettes smoked per day $\mathrm{x}$ the number of years smoked. The Ethics Committee of the School of Medicine, University of Rijeka, Croatia approved the present study, and written informed consent was obtained from each subject after the study's purpose and methods were described. The study was performed in accordance with the ethical standards stated in the latest version of the Declaration of Helsinki (45).

Genotyping. Peripheral blood leukocytes were obtained as described previously (46), and genomic DNA was extracted using a FlexiGene DNA kit 250 (QIAGEN GmbH) according to the manufacturer's protocol. Genotyping was performed using allele-specific PCR as described previously (23). PCR amplification was performed on a Mastercycler personal (Eppendorf) and 2720 Thermal Cycler (Applied Biosystems; Thermo Fisher Scientific, Inc.). The polymorphism detected by PCR was characterized by an $\sim 490$ bp fragment in the presence of the ACE-I allele and as an $~ 190$ bp fragment in the presence of the ACE-D allele. The PCR products were separated on $2 \%$ agarose gels and DNA was visualized using ethidium bromide staining under ultraviolet light. Each DNA sample appeared in one of three possible forms: A $490 \mathrm{bp}$ band (ACE-II genotype), a $190 \mathrm{bp}$ band (ACE-DD genotype), or both 490 and $190 \mathrm{bp}$ bands (ACE-ID genotype). To avoid mistyping of the ACE-ID heterozygotes as ACE-DD homozygotes, all of the ACE-DD genotype samples were additionally confirmed using insertion-specific PCR as described previously (47).

Statistical analysis. Statistica for Windows version 12 was used to perform the statistical analysis. Data are presented as the mean \pm standard deviation. The ACE genotype and allele distributions amongst smokers and non-smokers, as well as the observed and expected genotype proportions according to Hardy-Weinberg equilibrium, were compared using a $\chi^{2}$ test with $2 \times 2$ and $3 \times 2$ contingency tables. Furthermore, odds ratios (ORs) and $95 \%$ confidence intervals (CIs) were used to examine the association between the ACE-II homozygous and ACE-ID heterozygous genotypes, and the risk of being a smoker amongst the male patients. The relationship between pack-year smoking history and the ACE genotype was assessed using a one-way ANOVA. Multiple regression analysis was used to examine the extent the ACE-I/D polymorphic variant contributed to pack-year smoking history amongst females with squamous cell carcinoma. $\mathrm{P}<0.05$ was considered to indicate a statistically significant difference.

\section{Results}

Sex-specific differences in the effects of the ACE-I/D polymorphism in various diseases and/or conditions (48-52), including cancer (53) and nicotine dependence (29), have been shown previously. Thus, all analyses for male and female patients were performed separately.

The smoking rate was higher for both male and female patients compared with the rate in the general Croatian population (54), with $~ 95 \%$ of males and two-thirds of the females classified as smokers. A significantly greater prevalence 
Table I. Characteristics of patients with lung cancer.

\begin{tabular}{|c|c|c|c|c|}
\hline Clinicopathological characteristics & Males, $\mathrm{n}=214(\%)$ & Females, $\mathrm{n}=91(\%)$ & F or $\chi^{2}$ & P-value \\
\hline Age at blood sampling & $65.9 \pm 10.4$ & $66.8 \pm 10.6$ & 0.39 & 0.532 \\
\hline \multicolumn{5}{|l|}{ Tumor type (\%) } \\
\hline Adenocarcinoma & $48(22.4)$ & $39(42.9)$ & 13.07 & $<0.001^{\mathrm{c}}$ \\
\hline Squamous cell carcinoma & $119(55.6)$ & $25(27.5)$ & 20.28 & $<0.0001^{\mathrm{d}}$ \\
\hline Other NSCLC & $26(12.1)$ & $15(16.5)$ & 1.03 & 0.310 \\
\hline Total NSCLC & $193(90.1)$ & $79(86.9)$ & 0.75 & 0.385 \\
\hline SCLC & $21(9.9)$ & $12(13.1)$ & 0.75 & 0.385 \\
\hline \multicolumn{5}{|l|}{ Tumor stage $(\%)$} \\
\hline $\mathrm{I}+\mathrm{II}$ & $43(20.1)$ & $28(30.8)$ & 4.07 & $0.043^{\mathrm{a}}$ \\
\hline III + IV & $171(79.9)$ & $63(69.2)$ & 4.07 & $0.043^{\mathrm{a}}$ \\
\hline \multicolumn{5}{|l|}{ Smoking behavior } \\
\hline Smokers/non-smokers & $204 / 10$ & $55 / 36$ & 60.68 & $<0.0001^{\mathrm{d}}$ \\
\hline Pack-year smoking history & $55.6 \pm 32.2$ & $40.3 \pm 24.3$ & 10.78 & $<0.01^{\mathrm{b}}$ \\
\hline
\end{tabular}

${ }^{\mathrm{a}} \mathrm{P}<0.05,{ }^{\mathrm{b}} \mathrm{P}<0.01,{ }^{\mathrm{c}} \mathrm{P}<0.001,{ }^{\mathrm{d}} \mathrm{P}<0.0001$. NSCLC, non-small cell lung cancer; SCLC, small cell lung cancer.

Table II. Frequency of angiotensin converting enzyme genotypes and alleles according to smoking status.

A, Males

\begin{tabular}{lcccc}
\hline Allele & Smokers, $\mathrm{n}=204(\%)$ & Non-smokers, $\mathrm{n}=10(\%)$ & $\chi^{2}$ & $\mathrm{df}$ \\
\hline DD & $61(29.9)$ & $7(70.0)$ & 7.09 & 2 \\
ID & $103(50.5)$ & $2(20.0)$ & & $0.029^{\mathrm{a}}$ \\
II & $40(19.6)$ & $1(10.0)$ & 4.79 & 1 \\
D allele & $225(55.1)$ & $16(80.0)$ & & $0.029^{\mathrm{a}}$ \\
I allele & $183(44.9)$ & $4(20.0)$ & & \\
\hline
\end{tabular}

B, Females

\begin{tabular}{|c|c|c|c|c|c|}
\hline Allele & Smokers, $\mathrm{n}=55(\%)$ & Non-smokers, $\mathrm{n}=36(\%)$ & $\chi^{2}$ & df & P-value \\
\hline DD & $18(32.8)$ & $10(27.8)$ & 0.25 & 2 & 0.881 \\
\hline ID & $24(43.6)$ & $17(47.2)$ & & & \\
\hline II & $13(23.6)$ & $9(25.0)$ & & & \\
\hline $\mathrm{D}$ allele & $60(54.5)$ & $37(51.4)$ & 0.17 & 1 & 0.676 \\
\hline I allele & $50(45.5)$ & $35(48.6)$ & & & \\
\hline
\end{tabular}

${ }^{\mathrm{a}} \mathrm{P}<0.05$.

of nicotine dependence and significantly higher pack-year smoking histories were observed amongst males compared with females $(\mathrm{P}<0.0001$ and $\mathrm{P}<0.01$, respectively; Table I). The allele and genotype frequencies for the ACE-I/D polymorphism are presented in Table II, according to the smoking status. The statistical power of the present study was $99 \%$ for detection of a 1.5-fold increase in ACE-D allele frequency and $80 \%$ for detection of a 1.5-fold increase in ACE-I allele frequency. Distribution of the ACE genotype amongst male or female patients, as well as in the male smokers and non-smokers, and female smokers and non-smokers, were consistent with the Hardy-Weinberg equilibrium $(\mathrm{P}>0.05)$. The ACE allele and genotype frequencies did not deviate significantly from those observed in the European population (55). No significant differences were observed in the genotype and allele distributions of ACE between the total male and female patients $(\mathrm{P}>0.05)$. Analysis of smokers and non-smokers separately showed a greater prevalence of the ACE-I allele amongst female non-smokers compared with male non-smokers $(48.6 \%$ vs. $20.0 \%$; $\mathrm{P}<0.05)$. Thus, the ACE-I/D polymorphic variant contributed significantly to the risk of nicotine dependence only for male patients (Table II). There was a significantly 
Table III. ACE-I/D polymorphism and severity of nicotine dependence.

\begin{tabular}{lcccc}
\hline Sex & $\begin{array}{c}\text { ACE } \\
\text { genotype }\end{array}$ & $\begin{array}{c}\text { Pack-year } \\
\text { smoking history }\end{array}$ & F & P-value \\
\hline Males & DD & $57.7 \pm 35.3$ & 0.51 & 0.600 \\
& ID & $56.0 \pm 32.2$ & & \\
Females & II & $51.2 \pm 27.1$ & & \\
& DD & $47.1 \pm 26.0$ & 1.14 & 0.326 \\
& ID & $35.7 \pm 19.5$ & & \\
& II & $39.2 \pm 29.2$ & & \\
\hline
\end{tabular}

ACE, angiotensin converting enzyme.

different ACE genotype distribution between male smokers and male non-smokers, with an increase in the ACE-I allele amongst male smokers vs. male non-smokers (44.9 vs. $20.0 \%$; $\mathrm{P}<0.05)$. Furthermore, males harboring the ACE-I allele (ACE-II homozygous and ACE-ID heterozygous) had a $\sim 5$-fold higher risk of becoming smokers than the ACE-DD homozygous carriers $(\mathrm{OR}=5.47,95 \% \mathrm{CI}=1.4-21.9 ; \mathrm{P}=0.016)$.

Whether the ACE-I/D polymorphism contributed to smoking severity was next determined. No significant association was found between the ACE-I/D polymorphism and pack-year smoking history in all lung cancer patients $(\mathrm{P}>0.05$; Table III). There was no significant association between the ACE-I/D polymorphism and pack-year smoking history in subgroups of males with different types of lung cancer (P>0.05; Table SI). In subgroups of females with different types of lung cancer, significant associations between the ACE-I/D polymorphism and pack-year smoking history was observed only for females with squamous cell carcinoma $(\mathrm{P}<0.05$; Table SII). Specifically, females with squamous cell carcinoma that harbored an ACE-I allele (ACE-II homozygous and ACE-ID heterozygous) had significantly lower pack-year smoking histories compared with those who were ACE-DD homozygous (37.1 \pm 14.1 vs. $57.0 \pm 29.1 ; \mathrm{F}=4.5 ; \mathrm{P}=0.046)$. The ACE-I/D polymorphism accounted for $\sim 17.6 \%$ of the smoking severity in this patient group $(\beta=-0.42$, multiple $\mathrm{R}^{2}$ change $=0.176 ; \mathrm{P}=0.046$ ).

\section{Discussion}

Molecular epidemiological studies suggest that a large number of genes and several environmental factors contribute to the etiology of nicotine dependence. This complexity represents a considerable challenge, but also underlies the potential benefits of genetics studies on nicotine dependence $(56,57)$. In the present study, whether smoking behavior amongst patients with lung cancer was influenced by a functional I/D polymorphism of the ACE gene was investigated. To date, several studies have shown the relevance of this polymorphic variant in both nicotine dependence and lung cancer (27,29,34-36). However, to the best of our knowledge, the present study is the first to address the potential role of the ACE-I/D polymorphism in nicotine dependence amongst patients with lung cancer.
The results of the present study suggested there was a sex-dependent influence of the ACE-I/D polymorphism on smoking behavior amongst patients with lung cancer. In addition, the ACE-I/D polymorphic variant had the opposite effects on the risk of nicotine dependence and smoking severity. The ACE-I/D polymorphism had a significant impact on the risk of nicotine dependence in male patients in this patient group, where the presence of the ACE-I allele contributed to a greater risk of being a smoker. These findings are not consistent with any of the previous reports on the potential relevance of the ACE-I/D polymorphism in the etiology of nicotine dependence (26-29), highlighting the presence of a mechanism by which the ACE-I/D polymorphism contributed to the risk of nicotine dependence in lung cancer which differs from that than in other diseases and/or conditions.

A protective effect of the ACE-I allele on pack-year smoking history amongst a subgroup of females with squamous cell carcinoma was identified. The ACE genotype satisfactorily described the severity of nicotine dependence in this patient group. These data are supportive of previous studies on the influence of the ACE-I/D polymorphism on smoking severity in a study on a German cohort (27), which suggested that the absence of the ACE-I allele (ACE-DD homozygosity) contributes to greater pack-year smoking history amongst healthy individuals as well as to a higher number of cigarettes smoked per day amongst patients suffering from depression. The protective effects of the ACE-I allele on the severity of nicotine dependence may be attributed to the functional properties of the ACE-I/D polymorphism. It has been established that subjects homozygous for the $\mathrm{D}$ allele have the highest ACE plasma levels, those homozygous for the ACE-I allele have the lowest levels and those who are ID heterozygous exhibit intermediate levels (24). Thus, it is possible that ACE-II homozygous and ACE-ID heterozygous individuals, due to lower ACE activity, release dopamine at lower concentrations in the mesolimbic dopaminergic reward pathway in their brains.

Several findings may account for the sex-specific differences of the ACE-I/D polymorphism observed in the present study (58-60). Postmenopausal women receiving estrogen replacement therapy may result in a genotype-associated decrease in ACE activity. A significant decrease in plasma ACE activity was observed either in women with the ACE-ID and ACE-II genotypes (59), and in those with the ACE-ID and ACE-DD genotypes (60). Estrogen may influence dopaminergic neurotransmission, as estrogen treatment has been shown to reduce dopamine receptor D2 levels in several regions of the rat brain (61). Dopaminergic response to cigarette smoking differs between men and women. In particular, males show a consistent and more rapid increase in activity of the ventral striatum; whereas females respond show a faster response in a subregion of the dorsal putamen (62).

The present study has several limitations. The recruited cohort consisted of a relatively small number of participants; thus, there is a possibility minor effects were not detected. In addition, there was an unbalanced number of male and female patients as well as smoking and non-smoking males, which may have led to statistical biases in the analyses. Thus, although the observed OR indicates a strong association between the increased risk of becoming a smoker and 
the presence of the ACE-I allele amongst male patients, these results should be interpreted with caution. Moreover, the sample group also lacked a group of healthy control participants and data regarding smoking behavior were based exclusively on self-reporting, which itself is prone to unintended bias. Finally, only one RAS-related polymorphism with a distribution that differed significantly only between a subgroup of patients with squamous cell carcinoma and control participants in our previous study was investigated in the present study (35).

In conclusion, our results highlight that the ACE-I/D polymorphism contributes to both the risk and the severity of nicotine dependence amongst patients with lung cancer. A significantly increased risk of being a smoker was identified for male patients carrying the ACE-I allele (ACE-II homozygous and ACE-ID heterozygous) compared with those who were ACE-DD homozygous; whereas, a subgroup of female smokers with squamous cell carcinoma carrying the ACE-I allele had significantly lower pack-year smoking histories compared with the ACE-DD homozygous carriers. In line with the results of our previous study showing that the ACE-DD genotype and the ACE-D allele significantly increased the risk of developing squamous cell carcinoma (35), the latter findings suggest that the ACE-I/D polymorphism may be indirectly associated with an increased risk of squamous cell carcinoma by influencing the severity of nicotine dependence. Further studies are required, which include patients with other diseases and/or conditions, to assess nicotine dependence with more specific methods, such as the Fagerstrom test, and to investigate the relevance of other RAS-related polymorphic variants in smoking behavior (such as those of angiotensinogen and angiotensin II receptors), to validate and expand upon the results of the present study. Another issue that warrants consideration is that ACE, in addition to angiotensin II, has other potential substrates, some of which influence dopaminergic neurotransmission and are proposed to be associated with lung cancer, such as substance $\mathrm{P}$ and neurotensin $(63,64)$. Finally, it has been shown that cigarette smoking may also influence ACE expression/activity. It has been observed that nicotine and its metabolites increased the expression and activity of ACE in human endothelial cells (65), enhanced RAS activation and increased the levels of circulating ACE in chronic cigarette smokers $(65,66)$.

\section{Acknowledgements}

We would like to thank Mrs. Ivana Pleša for her excellent technical assistance.

\section{Funding}

This study was supported by grants from the University of Rijeka, Croatia (grant nos. 13.06.1.1.10, 13.11.1.2.10 and uniri-biomed-18-251).

\section{Availability of data and materials}

The datasets used and/or analyzed during the present study are available from the corresponding author on reasonable request.

\section{Authors' contributions}

SN designed the study, performed the data analysis and wrote the manuscript. VF recruited the patients, performed the medical examinations and drafted the manuscript. SDP performed the experiments and the data analysis. DV recruited the patients. ARB and MK interpreted the data, and drafted and revised the manuscript. SR designed and supervised the study as well as drafted the manuscript. All the authors read and approved the final manuscript.

\section{Ethics approval and consent to participate}

The Ethics Committee of the School of Medicine, University of Rijeka, Croatia approved the present study, and written informed consent was obtained from each subject after the study's purpose and methods were described. The study was performed in accordance with the ethical standards stated in the latest version of the Declaration of Helsinki.

\section{Patient consent for publication}

Not applicable.

\section{Competing interests}

The authors declare that they have no competing interests.

\section{References}

1. Yokota J, Shiraishi K and Kohno T: Genetic basis for susceptibility to lung cancer: Recent progress and future directions. Adv Cancer Res 109: 51-72, 2010.

2. Dela Cruz CS, Tanoue LT and Matthay RA: Lung cancer: Epidemiology, etiology, and prevention. Clin Chest Med 32: 605-644, 2011.

3. Pesch B, Kendzia B, Gustavsson P, Jöckel KH, Johnen G, Pohlabeln H, Olsson A, Ahrens W, Gross IM, Brüske I, et al: Cigarette smoking and lung cancer-relative risk estimates for the major histological types from a pooled analysis of case-control studies. Int J Cancer 131: 1210-1219, 2012.

4. Carmines EL: Evaluation of the potential effects of ingredients added to cigarettes. Part 1: Cigarette design, testing approach, and review of results. Food Chem Toxicol 40: 77-91, 2002.

5. Baker RR, Pereira da Silva JR and Smith G: The effect of tobacco ingredients on smoke chemistry. Part I: Flavourings and additives. Food Chem Toxicol 42 (Suppl): S3-S37, 2004.

6. Greenbaum L and Lerer B: Differential contribution of genetic variation in multiple brain nicotinic cholinergic receptors to nicotine dependence: Recent progress and emerging open questions. Mol Psychiatry 14: 912-945, 2009.

7. Lassi G, Taylor AE, Timpson NJ, Kenny PJ, Mather RJ, Eisen T and Munafò MR: The CHRNA5-A3-B4 gene cluster and smoking: From discovery to therapeutics. Trends Neurosci 39: 851-861, 2016.

8. Dani JA and Harris RA: Nicotine addiction and comorbidity with alcohol abuse and mental illness. Nat Neurosci 8: 1465-1470, 2005.

9. Drew AE, Derbez AE and Werling LL: Nicotinic receptor-mediated regulation of dopamine transporter activity in rat prefrontal cortex. Synapse 38: 10-16, 2000.

10. Fowler JS, Logan J, Wang GJ and Volkow ND: Monoamine oxidase and cigarette smoking. Neurotoxicology 24: 75-82, 2003.

11. Sagud M, Mihaljević-Peles A, Mück-Seler D, Pivac N, Vuksan-Cusa B, Brataljenović T and Jakovljević M: Smoking and schizophrenia. Psychiatr Danub 21: 371-375, 2009.

12. D'Souza MS and Markou A: Neuronal mechanisms underlying development of nicotine dependence: Implications for novel smoking-cessation treatments. Addict Sci Clin Pract 6: 4-16, 2011. 
13. Hecht SS: Tobacco carcinogens, their biomarkers and tobacco-induced cancer. Nat Rev Cancer 3: 733-744, 2003.

14. Bierut LJ, Madden PA, Breslau N, Johnson EO, Hatsukami D, Pomerleau OF, Swan GE, Rutter J, Bertelsen S, Fox L, et al: Novel genes identified in a high-density genome wide association study for nicotine dependence. Hum Mol Genet 16: 24-35, 2007.

15. Saccone SF, Hinrichs AL, Saccone NL, Chase GA, Konvicka K, Madden PA, Breslau N, Johnson EO, Hatsukami D, Pomerleau O, et al: Cholinergic nicotinic receptor genes implicated in a nicotine dependence association study targeting 348 candidate genes with 3713 SNPs. Hum Mol Genet 16: 36-49, 2007.

16. Amos CI, Wu X, Broderick P, Gorlov IP, Gu J, Eisen T, Dong Q, Zhang Q, Gu X, Vijayakrishnan J, et al: Genome-wide association scan of tag SNPs identifies a susceptibility locus for lung cancer at 15q25.1. Nat Genet 40: 616-622, 2008.

17. Wosik K, Cayrol R, Dodelet-Devillers A, Berthelet F, Bernard M, Moumdjian R, Bouthillier A, Reudelhuber TL and Prat A: Angiotensin II controls occludin function and is required for blood brain barrier maintenance: Relevance to multiple sclerosis. J Neurosci 27: 9032-9042, 2007.

18. Nawaz SK and Hasnain S: Pleiotropic effects of ACE polymorphism. Biochem Med 19: 36-49, 2008

19. van der Knaap R, Siemes C, Coebergh JW, van Duijn CM, Hofman A and Stricker BH: Renin-angiotensin system inhibitors, angiotensin I-converting enzyme gene insertion/deletion polymorphism, and cancer: The rotterdam study. Cancer 112: 748-757, 2008.

20. van Haaster MC, McDonough AA and Gurley SB: Blood pressure regulation by the angiotensin type 1 receptor in the proximal tubule. Curr Opin Nephrol Hypertens 27: 1-7, 2018.

21. Jenkins TA, Allen AM, Chai SY, MacGregor DP, Paxinos G and Mendelsohn FA: Interactions of angiotensin II with central dopamine. Adv Exp Med Biol 396: 93-103, 1996.

22. Jenkins TA, MendelsohnFA and ChaiSY: Angiotensin-converting enzyme modulates dopamine turnover in the striatum. J Neurochem 68: 1304-1311, 1997.

23. Obata T, Takahashi S, Kashiwagi Y and Kubota S: Protective effect of captopril and enalaprilat, angiotensin-converting enzyme inhibitors, on para-nonylphenol-induced $* \mathrm{OH}$ generation and dopamine efflux in rat striatum. Toxicology 250: 96-99, 2008.

24. Rigat B, Hubert C, Alhenc-Gelas F, Cambien F, Corvol P and Soubrier F: An insertion/deletion polymorphism in the angiotensin I-converting enzyme gene accounting for half the variance of serum enzyme levels. J Clin Invest 86: 1343-1346, 1990.

25. Hubacek JA, Pitha J, Skodova Z and Poledne R: Angiotensin converting enzyme gene-a candidate gene for addiction to smoking? Atherosclerosis 159: 237-238, 2001.

26. Hubacek JA, Adamkova V, Skodova Z, Lanska V and Poledne R: No relation between angiotensin-converting enzyme gene polymorphism and smoking dependence. Scand J Clin Lab Invest 64 575-578, 2004

27. Baghai TC, Varallo-Bedarida G, Born C, Häfner S, Schule C, Eser D, von Schacky C, Rupprecht R and Bondy B: A polymorphism in the angiotensin-converting enzyme gene is associated with smoking behavior. J Clin Psychiatry 69: 1983-1985, 2008

28. Nadalin S, Buretić-Tomljanović A, Lavtar P, Starčević Čizmarević N, Hodžić A, Sepčić J, Kapović M, Peterlin B and Ristić S: The lack of association between angiotensin-converting enzyme gene insertion/deletion polymorphism and nicotine dependence in multiple sclerosis. Brain Behav 7: e00600, 2016.

29. Nadalin S, Ristić S, Rebić J, Sendula Jengić V, Kapović M and Buretić-Tomljanović A: The insertion/deletion polymorphism in the angiotensin-converting enzyme gene and nicotine dependence in schizophrenia patients. J Neural Transm (Vienna) 124 511-518, 2017.

30. Cheon KT, Choi KH, Lee HB, Park SK, Rhee YK and Lee YC: Gene polymorphisms of endothelial nitric oxide synthase and angiotensin-converting enzyme in patients with lung cancer. Lung 178: 351-360, 2000.

31. Wang HW, Nie ZS, Duan YZ, Liu DD, Han ZH, Zhang XH and Hua B: Association between polymorphism in ACE gene with lung cancer and COPD patients. Bei Jing Yi Xue 22: 364-365, 2000 (In Chinese).

32. Zhang Q, Liu X, Zhang Z and Wang L: Analysis of the relationship between polymorphism of angiotensin-converting enzyme gene and lung cancer. Zhongguo Fei Ai Za Zhi 8: 211-214, 2005 (In Chinese).

33. Yaren A, Oztop I, Turgut S, Turgut G, Degirmencioglu S and Demirpence M: Angiotensin-converting enzyme gene polymorphism is associated with anemia in non small-cell lung cancer. Exp Biol Med (Maywood) 233: 32-37, 2008.
34. Nacak M, Nacak I, Sanli M, Ozkur M, Pektas M and Aynacioğlu AS: Association of angiotensin converting enzyme gene insertion/deletion polymorphism with lung cancer in Turkey. Cancer Genet Cytogenet 198: 22-26, 2010.

35. Dević Pavlić S, Ristić S, Flego V, Kapović M and Radojčić Badovinac A: Angiotensin-converting enzyme insertion/deletion gene polymorphism in lung cancer patients. Genet Test Mol Biomarkers 16: 722-725, 2012.

36. Peddireddy V, Badabagni SP, Gundimeda SD and Mundluru HP: Association of eNOS and ACE gene polymorphisms and plasma nitric oxide with risk of non-small cell lung cancer in South India. Clin Respir J 12: 207-217, 2018.

37. Gao M, Wang Y, Shi Y, Liu D, Liang Y, Yu Y, Zhaobin J, Zhu L and Jin S: The relationship between three well-characterized polymorphisms of the angiotensin converting enzyme gene and lung cancer risk: A case-control study and a meta-analysis. J Renin Angiotensin Aldosterone Syst 13: 455-460, 2012.

38. Cheng Z, Ma R, Tan W, Zhang L and Tan Q: Lack of association between $\mathrm{ACE}$ insertion/deletion polymorphism and lung cancer: A meta-analysis. J Renin Angiotensin Aldosterone Syst 16: 453-458, 2015.

39. Wang N, Yang D, Ji B and Li J: Angiotensin-converting enzyme insertion/deletion gene polymorphism and lung cancer risk: A meta-analysis. J Renin Angiotensin Aldosterone Syst 16: 189-194, 2015.

40. Satoh H, Yamashita YT, Ishikawa H, Kamma H, Ohtsuka M and Sekizawa K: Smoking and smoking-related lung cancer in female patients. Anticancer Res 19: 5627-5630, 1999.

41. Travis WD, Brambilla E, Nicholson AG, Yatabe Y, Austin JHM, Beasley MB, Chirieac LR, Dacic S, Duhig E, Flieder DB, et al: The 2015 world health organization classification of lung tumors: Impact of genetic, clinical and radiologic advances since the 2004 classification. J Thorac Oncol 10: 1243-1260, 2015.

42. Detterbeck FC, Boffa DJ, Kim AW and Tanoue LT: The eighth edition lung cancer stage classification. Chest 151: 193-203, 2017.

43. de Leon J and Diaz FJ: A meta-analysis of worldwide studies demonstrates an association between schizophrenia and tobacco smoking behaviors. Schizophr Res 76: 135-157, 2005.

44. Guo S, Chen DF, Zhou DF, Sun HQ, Wu GY, Haile CN, Kosten TA, Kosten TR and Zhang XY: Association of functional catechol O-methyl transferase (COMT) Val108Met polymorphism with smoking severity and age of smoking initiation in Chinese male smokers. Psychopharmacology (Berl) 190: 449-456, 2007.

45. Carlson RV, Boyd KM and Webb DJ: The revision of the declaration of Helsinki: Past, present and future. Br J Clin Pharmacol 57: 695-713, 2004.

46. Qiagen: FlexiGene DNA Handbook. https://www.qiagen $\mathrm{com} / \mathrm{us} /$ resources/resourcedetail?id=6b147421-7846-411e-9993bb01563b807e\&lang=en. Accessed March 6, 2020

47. Shanmugam V, Sell KW and Saha BK: Mistyping ACE heterozygotes. PCR Methods Appl 3: 120-121, 1993.

48. Lovrecić L, Ristić S, Starcević-Cizmarević N, Jazbec SS, Sepcić J, Kapović M and Peterlin B: Angiotensin-converting enzyme I/D gene polymorphism and risk of multiple sclerosis. Acta Neurol Scand 114: 374-377, 2006.

49. Sipahi T, Budak M, Şen S, Ay A and Şener S: Association between ACE gene insertion (I)/deletion (D) polymorphism and primary hypertension in Turkish patients of Trakya region. Biotechnol Biotechnol Equip 20: 104-108, 2006.

50. Nadalin S, Buretić-Tomljanović A, Rubeša G, Jonovska S, Tomljanović D and Ristić S: Angiotensin-converting enzyme gene insertion/deletion polymorphism is not associated with schizophrenia in a Croatian population. Psychiatr Genet 22: 267-268, 2012.

51. Avila-Vanzzini N, Posadas-Romero C, Gonzalez-Salazar Mdel C, Maass-Iturbide C, Melendez-Ramirez G, Perez-Mendez O, Del Valle-Mondragon L, Masso-Rojas F, Varela Lopez E, Herrera-Bello $\mathrm{H}$, et al: The ACE I/D polymorphism is associated with nitric oxide metabolite and blood pressure levels in healthy Mexican men. Arch Cardiol Mex 85: 105-110, 2015.

52. Nadalin S, Buretić-Tomljanović A, Ristić S, Jonovska S and Tomljanović D: The impact of ACE gene I/D polymorphism on plasma glucose and lipid concentrations in schizophrenia patients. Psychiatry Res 227: 71-72, 2015.

53. Röcken C, Neumann K, Carl-McGrath S, Lage H, Ebert MP, Dierkes J, Jacobi CA, Kalmuk S, Neuhaus P and Neumann U: The gene polymorphism of the angiotensin I-converting enzyme correlates with tumor size and patient survival in colorectal cancer patients. Neoplasia 9: 716-722, 2007. 
54. Turek S, Rudan I, Smolej-Narancić N, Szirovicza L, Cubrilo-Turek M, Zerjavić-Hrabak V, Rak-Kaić A, Vrhovski-Hebrang D, Prebeg Z, Ljubicić M, et al: A large cross-sectional study of health attitudes, knowledge, behaviour and risks in the post-war Croatian population (the first Croatian health project). Coll Antropol 25: 77-96, 2001.

55. National Center for Biotechnology Information, U.S. National Library of Medicine: rs1799752 [Homo sapiens]. https://www.ncbi. nlm.nih.gov/snp/?term=rs1799752. Accessed March 6, 2020

56. Li MD: Identifying susceptibility loci for nicotine dependence: 2008 update based on recent genome-wide linkage analyses. Hum Genet 123: 119-131, 2008.

57. Bierut LJ: Convergence of genetic findings for nicotine dependence and smoking related diseases with chromosome 15q24-25. Trends Pharmacol Sci 31: 46-51, 2010.

58. Gallagher PE, Li P, Lenhart JR, Chappell MC and Brosnihan KB: Estrogen regulation of angiotensin-converting enzyme mRNA. Hypertension 33: 323-328, 1999.

59. Sanada M, Higashi Y, Nakagawa K, Sasaki S, Kodama I, Tsuda M, Nagai N and Ohama K: Relationship between the angiotensin-converting enzyme genotype and the forearm vasodilator response to estrogen replacement therapy in postmenopausal women. J Am Coll Cardiol 37: 1529-1535, 2001.

60. Sumino H, Ichikawa S, Ohyama Y, Nakamura T, Kanda T, Sakamoto H, Sakamaki T, Mizunuma $\mathrm{H}$ and Kurabayashi M: Effects of hormone replacement therapy on serum angiotensin-converting enzyme activity and plasma bradykinin in postmenopausal women according to angiotensin-converting enzyme-genotype. Hypertens Res 26: 53-58, 2003.
61. Chavez C, Hollaus M, Scarr E, Pavey G, Gogos A and van den Buuse M: The effect of estrogen on dopamine and serotonin receptor and transporter levels in the brain: An autoradiography study. Brain Res 1321: 51-59, 2010.

62. Cosgrove KP, Wang S, Kim SJ, McGovern E, Nabulsi N, Gao H, Labaree D, Tagare HD, Sullivan JM and Morris ED: Sex differences in the brain's dopamine signature of cigarette smoking. J Neurosci 34: 16851-16855, 2014

63. Alifano M, Souazé F, Dupouy S, Camilleri-Broët S, Younes M, Ahmed-Zaïd SM, Takahashi T, Cancellieri A, Damiani S, Boaron M, et al: Neurotensin receptor 1 determines the outcome of non-small cell lung cancer. Clin Cancer Res 16: 4401-4410, 2010.

64. Muñoz M, González-Ortega A, Rosso M, Robles-Frias MJ, Carranza A, Salinas-Martín MV and Coveñas R: The substance $\mathrm{P} /$ neurokinin-1 receptor system in lung cancer: Focus on the antitumor action of neurokinin-1 receptor antagonists. Peptides 38: 318-325, 2012

65. Ljungberg L, Alehagen U, Länne T, Björck H, De Basso R, Dahlström $U$ and Persson K: The association between circulating angiotensin-converting enzyme and cardiovascular risk in the elderly: A cross-sectional study. J Renin Angiotensin Aldosterone Syst 12: 281-289, 2011.

66. Laustiola KE, Lassila R and Nurmi AK: Enhanced activation of the renin-angiotensin-aldosterone system in chronic cigarette smokers: A study of monozygotic twin pairs discordant for smoking. Clin Pharmacol Ther 44: 426-430, 1988. 